\title{
Current insights into skin banking: storage, preservation and clinical importance of skin allografts
}

This article was published in the following Dove Press journal: Journal of Biorepository Science for Applied Medicine 18 July 2017

Number of times this article has been viewed

\author{
Linda Tognetti ${ }^{1,2}$ \\ Elisa Pianigiani' \\ Francesca lerardi' \\ Giancarlo Mariotti' \\ Roberto Perotti' \\ Antonio Di Lonardo 3 \\ Pietro Rubegni' \\ Michele Fimiani'
}

'Dermatology Unit and Skin Bank, Department of Medical, Surgical and Neuro-Sciences, University Hospital of Siena, ${ }^{2}$ Department of Medical Biotechnologies, University of Siena, Siena, ${ }^{3}$ Burn Unit, Cisanello Hospital, Azienda Ospedaliera Universitaria Pisana (AOUP), Pisa, Italy
Correspondence: Linda Tognetti Dermatology Unit and Skin Bank, Department of Medical, Surgical and Neuro-Sciences, University Hospital of Siena, "Le Scotte" Hospital - AOUS, Viale Bracci, 53100 Siena, Italy Email linda.tognetti@gmail.com

\begin{abstract}
Donor skin and dermal grafts are used in several types of loss of substance for different clinical purposes. As biological physiological medication, donor skin grafts can promote re-epithelization, shorten healing time, alleviate pain and protect dermal and subcutaneous structures such as cartilage, tendons, bones and nerves. Though a great variety of dermal matrices and skin equivalents, both synthetic and semisynthetic, are now available for wound treatment, viable human skin allografts remain an important therapeutic choice for extensive deep burns and hard-to-heal wounds. In such cases, viable skin allografts have significantly better clinical outcomes than unviable human-derived allografts or synthetic medications. The demand for human-derived skin bioproducts continues to be a reason for the existence of skin banks. Skin bank organization is complex and requires continuous updating. Careful donor selection, thorough microbiological and serological donor screening for transmissible diseases and rigorous quality control during tissue preparation are necessary to minimize the risk of transmission of pathogenic agents. Skin banks must also observe standardized reproducible procedures to ensure tissue traceability and biological safety in all phases of processing and to avoid new biological contamination. Constant training and periodic checks are needed to keep skin bank operators attentive and responsible. Finally, skin banks should guarantee collection and storage of highly viable skin. Here, we discuss available tissue storage methods and the different types of skin bioproducts.
\end{abstract}

Keywords: skin allografts, storage methods, skin bioproducts, skin viability

\section{History of skin banking: past, present and future expectation}

Until the beginning of the 20th century, it was not possible to bank skin because it was difficult to maintain tissue viability. Modern skin preservation began with successful storage at $+4^{\circ} \mathrm{C}$ and $+7^{\circ} \mathrm{C}$ by Webster ${ }^{1}$ and Matthew ${ }^{2}$, respectively. After experiments with refrigerated cow skin, Webster managed to successfully store fresh human skin autografts for 3 weeks. Tissue banking procedures started in the 1930-1940s, when efficient, reproducible, standardized storage methods became available. During World War II and the Vietnam War, numerous studies were conducted on skin allografting to treat military burns and wounds. ${ }^{3,4}$ The first officially recognized skin bank, the US Navy Skin Bank, was set up in the USA in 1949 (Figure 1). ${ }^{4}$ Many skin banks were established in the USA in the 1950-1960s, whereas most European tissue banks were set up in the 1970 and 1980s: such banks were mainly organized for storage of many different tissues, such as the bone and skin. ${ }^{4-8}$ Two notable exceptions were the University Hospital in Hradec Kralove' (Czech Republic) ${ }^{5}$ and the Yorkshire Regional Tissue 


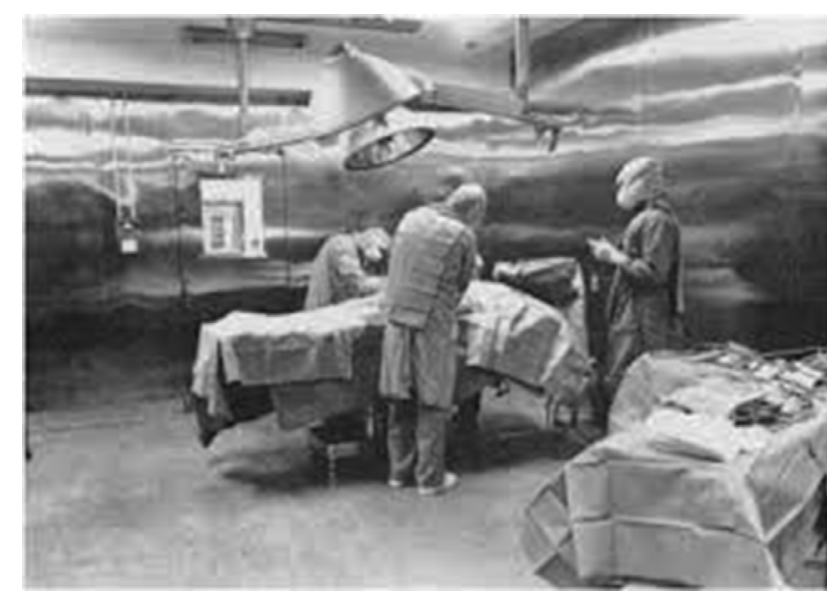

Figure I Procurement at the US Navy Tissue Bank, Bethesda, Maryland (1950). Note: Cell and Tissue Banking, The US Navy Tissue Bank: 50 years on the cutting edge, I (I), 2000, 9-16, Strong DM, with permission of Springer. ${ }^{77}$

Bank, founded in 1952 and 1960, respectively. ${ }^{6}$ Donor skin procurement, processing and banking were introduced in Italy in the mid-1990s to meet the growing demand for transplant tissue. $^{7}$ The first laboratories were created as centers for the treatment of severe burns; they were later organized into more complex structures (tissue establishments), including skin banks. A skin bank was defined as an organization having sufficient structure, equipment, laboratories and know-how to ensure safety and efficacy of the entire tissue banking process. The complex organization supporting the donation process was drawn from the Spanish model (i.e., Organización Nacional de Trasplantes). ${ }^{8}$ The Donor Tissue Bank of Victoria is active from 1995. To meet the enormous need of burn wound coverage, several skin banks were set up during the past few decades. Currently, there are four skin banks in Brazil, the latter opened in 2013, and one in Mexico from 2003. The first skin bank of India and Africa were established in 2010 and 2016, respectively. ${ }^{9-11}$

A synthetic or semisynthetic skin substitute/dressing with biological properties similar to fresh viable human skin has yet to be developed, and autologous grafting is still considered the gold standard treatment for deep burns and other types of skin loss. However, skin autografting is often impossible in burn patients, due to a lack of healthy skin donor sites and to the general condition of these patients. Human cadaver skin grafts are therefore still the best alternative for wound coverage. ${ }^{12-14}$ Moreover, as the median age of the population increases, the number of people with hard-to-heal wounds, such as posttraumatic wounds in patients with diabetes or on long-term therapy with high-dose corticosteroids, chronic venous and pressure ulcers, is increasing. The increasing demand for donor skin grafts to manage severe burns, trauma and soft tissue injuries has led to the creation of skin bank- ing facilities, ${ }^{14}$ stimulating research into skin processing methods. ${ }^{12-17}$

All patients provided written informed consent for their accompanying images to be published for this review.

\section{Practice guidelines}

Today, four tissue banks are active in the USA and operate according to American Association of Tissue Banking guidelines and federal laws. ${ }^{7,9}$ In Europe, skin banks comply with the European Association of Tissue Banks standards for skin banking and banking of skin substitutes or with specific guidelines, such as that of the British Association of Tissue Banks, and national legislation. European directives (2004/23/EC, ${ }^{18}$ 2006/17/EC, ${ }^{19} 2006 / 86 /$ EC $^{20}$ ) outlining Good Manufacturing Practices (GMP) (EU Guidelines GMP 2008) were recently issued. ${ }^{21}$

In Australia, the donation of human tissue is regulated by legislation from the late 1970s: tissue banking is regulated as a therapeutic resource (i.e., Therapeutic Goods Act 1989); thus, tissue banks are required to be licensed by the Therapeutic Goods Administration and must comply with the code of GMP-human blood and tissues. ${ }^{22}$

In Italy, pharmaceutical laboratories and cell factories rigorously observe GMP guidelines and must be certified, ${ }^{21}$ whereas tissue establishments comply with GMP that do not completely regulate the sector; ${ }^{23}$ international guidelines by the Council of Europe ${ }^{24}$ help harmonize procedures and standards of different countries to promote tissue exchange. Tissue banks interact with international scientific nonprofit networks promoting development and research in tissue banking. ${ }^{25}$ Quality standards mostly refer to internationally recognized standards such as ISO 9001 (to ensure a traceable standardized quality system) and GMP guidelines. GMP conformity ensures, inter alia, that environmental parameters are constantly monitored for particulate and microbial contamination, and structures and equipment are regularly calibrated, maintained and validated according to written procedures, the frequency of which is set according to the importance of the process. ${ }^{24,25}$

Strict adherence to GMP suggests that aseptic processing in European Union (EU) countries should take place in Grade A conditions with Grade B background environment. According to EU directives, ${ }^{17}$ processing areas of tissue establishments set up in the EU should be classified as Grade A with a surrounding environment of at least Grade D.

\section{Skin bank structure}

The Tuscan Region Skin Bank has a quality management system with ISO 9001 certification since 2003; the skin bank 
is included in the Italian network authorized by the National Transplant Centre. ${ }^{23}$ Italian skin banks process skin in Grade A laminar flow cabinets with a background GMP-Grade B environment, in line with national regulations. ${ }^{23}$ The laboratory is defined as a "contamination controlled area" because it is composed of differently classified rooms (classes A/B, C, D), high-efficiency particulate air filter with positive pressure (Biosafety Level 2), constant thermo-hygrometric parameters and monitoring for particle/microbial contamination. ${ }^{7,23-26}$ The skin bank of Siena currently procures, processes and stores more than 130 donations per year, obtaining about $300,000 \mathrm{~cm}^{2}$ per year of homologous skin for clinical use (Figure 2). ${ }^{7}$

\section{Skin procurement}

Skin procurement teams should consist of at least two people operating under aseptic conditions and appropriately clothed for the type of procurement. Staff must have the necessary experience, education and training to correctly perform recovery operations. In some European countries, skin procurement from cadavers is carried out by a team of authorized medical practitioners (e.g., Spain and Italy) or fully trained nonmedical practitioners under medical responsibility (e.g., the UK and the Netherlands), since European directives state that procurement "shall be carried out by persons who have successfully completed a training program specified by a clinical team." ${ }^{\prime 19}$ The retrieval team is usually contacted by transplant coordinators. ${ }^{17,19,20}$

In Italy, skin procurement can only be carried out by authorized medical practitioners on call $24 \mathrm{~h}$ a day. ${ }^{17,20} \mathrm{In}$ the USA, tissue is procured by personnel working for tissue recovery agencies. According to federal laws, these agencies must be registered with the Food and Drug Administration (FDA) and observe FDA regulations governing tissue recovery. $^{27}$

In Italy, tissue donors can be between 14 and 78 years of age. ${ }^{23}$ Skin can be procured from deceased heart-beating multiorgan donors and deceased non-heart-beating multitissue
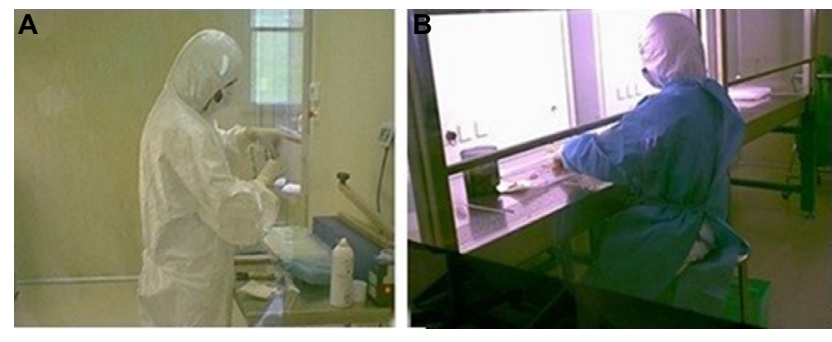

Figure 2 Different phases of processing of skin allograft procedure (A) and quality control in Grade B area (B). donors. For heart-beating multiorgan donors, skin is procured after circulation has ceased. In the USA, non-heart-beating donor skin can be harvested until $24 \mathrm{~h}$ after death if the body is refrigerated or cooled within $12 \mathrm{~h}$ of death; if the body is not cooled nor refrigerated, skin procurement must be carried out within $15 \mathrm{~h}$ of death. ${ }^{27}$ The EU directive does not state any specific timing for the harvesting phases, but many countries procure skin within $12 \mathrm{~h}$ of death if the body is not refrigerated, and within $24 \mathrm{~h}$ only if the body is refrigerated within $6 \mathrm{~h}$ of death. ${ }^{18-23}$

Skin refrigeration before procurement has some advantages. First, the consistency of subcutaneous tissues is harder, which mechanically facilitates the harvesting operation. The skin contamination rate may also be reduced. ${ }^{7,16}$

Procurement from living donors is carried out with the same standards as for cadaver donors: in most cases, living donors are patients undergoing abdominoplasty who consent to tissue donation.

During procurement, perfect coordination between the different surgical teams is mandatory to limit the risk of tissue contamination. ${ }^{24}$ To reduce the degree of microbial contamination, the donor is appropriately cleansed with povidone-iodine scrub solution, rinsed with sterile saline and disinfected with chlorhexidine tincture. In our experience, shaving helps reduce resident microbial flora living primarily in and around hair follicles. The sequence in which tissues are procured should be defined to assure their quality. Skin should be procured before musculoskeletal tissues, because the presence of bones facilitates the procedure without increased risk of tissue contamination. ${ }^{24}$

Skin layers that are $400-800 \mu \mathrm{m}$ thick are cut from the posterior trunk and the lower limbs by battery-operated dermatome, such as the Aesculap-GA630, ${ }^{7}$ or electric dermatome, such as the Braun Medical ${ }^{17}$ or the Zimmer Electric Dermatome (Figure 3).

Good manual skills ensure samples of uniform thickness and sufficient width, suitable for treating major burns. Retrieved tissue is transported to the tissue bank, where data recording and processing phases are activated in laboratory clean rooms or specific areas. After procurement, the cadaver is covered with absorbent pads and/or Tyvek garments to prevent leakage; in some cases, sealing polymers can be used as anti-oozing agents. The skin allografts are placed in sealed sterile containers filled with a specific transport medium supplemented with a combination of antibiotics, according to validated skin bank protocols. In our skin bank, $0.9 \%$ saline solution supplemented with $100 \mathrm{IU} / \mathrm{mL}$ penicillin and $100 \mu \mathrm{g} / \mathrm{mL}$ streptomycin is used as transport 


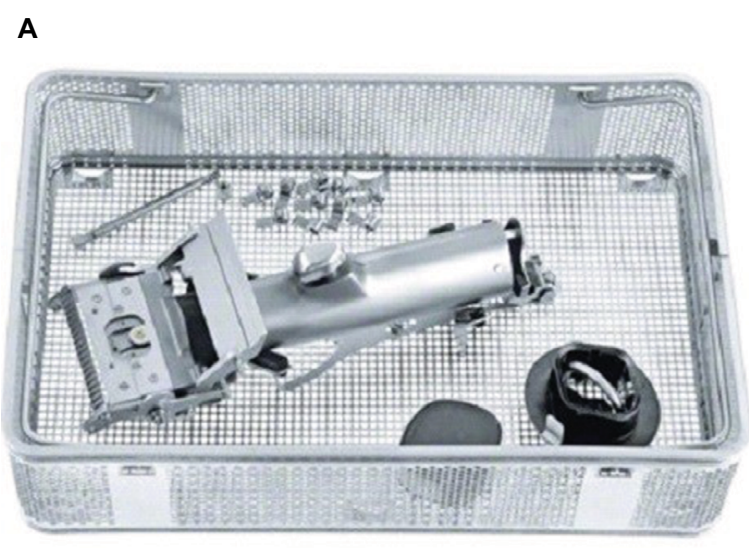

B

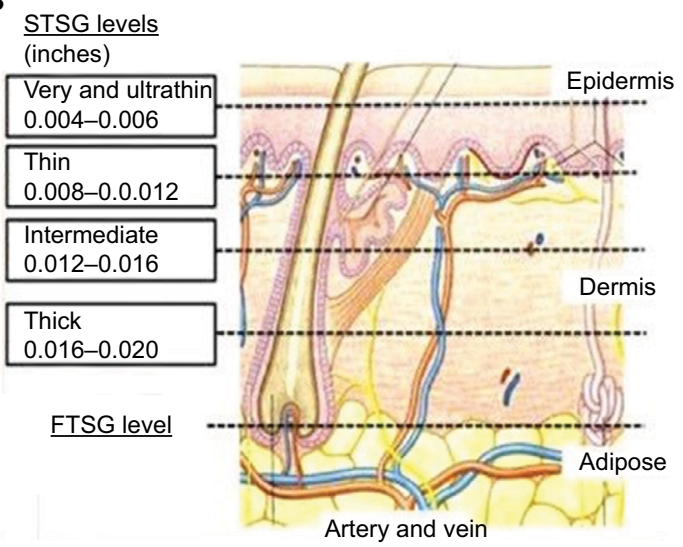

Figure 3 Battery-operated dermatome Aesculap-GA630 (A) and harvesting levels (B) determining skin allograft thickness. Abbreviations: FTSG, full thickness skin graft; STSG, split thickness skin graft.

medium. ${ }^{7,28}$ Other authors prefer Ringer lactate or RPMI 1640 supplemented with $320 \mathrm{mg} / \mathrm{L}$ gentamicin, $500 \mathrm{mg} / \mathrm{L}$ vancomycin and $600 \mathrm{mg} / \mathrm{L}$ lincomycin (per $100 \mathrm{~mL}$ of transport medium, respectively). ${ }^{17}$ Others employ transport solution composed of $800 \mathrm{~mL}$ custom-made medium for culturing epithelial cells, consisting of Dulbecco's Modified Eagle Medium (DMEM) /Ham's F12 Nutrient mix and $10.6 \mathrm{~g} / \mathrm{L}$ sodium bicarbonate $3: 1$, supplemented with $200 \mathrm{~mL}$ of custom-made Cambridge Antibiotic Solution, consisting of gentamycin sulfate $4 \mathrm{~g} / \mathrm{L}$, primaxin $0.2 \mathrm{~g} / \mathrm{L}$, polymyxin B $0.2 \mathrm{~g} / \mathrm{L}$, vancomycin $0.05 \mathrm{~g} / \mathrm{L}$ and nystatin 2,500,000 U/L in Medium 199 with $25 \mathrm{mM}$ HEPES). ${ }^{29} \mathrm{The}$ containers are then transferred to the skin bank in refrigerated tanks $\left(+4^{\circ} \mathrm{C}\right)$.

\section{Donor screening and selection}

Skin banks should regulate all their activities, including procurement, data recording, processing, storage, distribution and import/export of tissues, ${ }^{18-20,30-33}$ according to written operating procedures detailed in technical guidelines. According to international guidelines and national legislation, the safety requirements of donor skin (whether from cadavers or living donors) must be guaranteed by special procedures and quality standards. ${ }^{15-19}$ To reduce the risk of transmission of diseases through skin transplantation, potential donors are selected on the basis of comprehensive medical and social (personal, behavioral) data, including travel history, physical examination and serological and microbiological testing. Minimum serological screening for HIV, hepatitis B and C and syphilis, and optional testing for human T-lymphotrophic virus, cytomegalovirus, $\mathrm{ABO}$ grouping and $\mathrm{Rh}$ typing are performed by most skin tissue banks. Exclusion criteria for skin donation include cancer, active infections, autoimmune or connective tissue diseases affecting the skin, diseases affecting the dermis (e.g., dermal mucinosis, nephrogenic fibrosing dermopathy, and porphyria), mechanical or microbial damage to the skin, burns at the body site where skin is to be procured and skin toxicity due to toxic agents or poisons..$^{18-24,32,33}$

\section{Processing of skin samples}

Processing methods must maintain the integrity and biological properties of tissues and cells. Processing time for cryopreservation or deep freezing needs to be brief to ensure cell viability. ${ }^{22-27}$ Skin is therefore processed according to validated skin bank protocols. Accuracy is required in the identification of tissue contamination indicators: microbiological quality control must be managed with particular attention, especially in phases where microbiological and particle counts are performed..$^{7,19,21,23}$ In parallel, the results have to coincide with those expected. ${ }^{18-27}$ Every tissue bank has its own processing protocols, which should be detailed in written procedures and validated.

During skin procurement in operating theaters or appropriate facilities, fragments of at least $5-10 \mathrm{~cm}^{2}$ are usually harvested from different body areas and incubated in sterile saline solution without antibiotics or culture media: these samples are used for microbiological testing. ${ }^{17-24}$

In our skin bank, skin to be cryopreserved or frozen is processed by incubation in normal saline and cryoprotectants supplemented with antibiotics, for example, DMEM, 15\% glycerol, $\mathrm{P} / \mathrm{S}$, gentamycin sulfate $100 \mu \mathrm{g} / \mathrm{mL}$ and amphotericin B $5 \mu \mathrm{g} / \mathrm{mL}$. In order to prepare de-epidermized dermis (DED), skin is de-epidermized manually. The dermis to be cryopreserved or frozen is then processed by consecutive changes of medium at intervals of $48 \mathrm{~h}$ : the first two in normal saline + penicillin/streptomycin and in normal saline + terbinafine $100 \mu \mathrm{g} / \mathrm{mL}$. Processed skin and DED are then packaged and frozen in a programmable slow-rate freezer 
Table I Recommendation for microbiological testing of skin samples

\begin{tabular}{llll}
\hline Microbic agent & Culture medium & Incubation temperature & Incubation period, days \\
\hline Aerobic and fungi & Soya bean casein digest medium & $20^{\circ} \mathrm{C}-25^{\circ} \mathrm{C}$ & 14 \\
Anaerobic & Fluid thioglycollate medium & $30^{\circ} \mathrm{C}-35^{\circ} \mathrm{C}$ & $\mid 4$ \\
\hline
\end{tabular}

Note: Data from European Directorate for the Quality of medicines \& Health Care (EDQM). Guide to the quality and safety of tissues and cells for human application. France; $2015 .^{24}$

(such as a Planer-Kryosave Integra, mod.750, Sunbury-OnThames, UK). After packaging and freezing, postprocessing samples are sent to the microbiology laboratory, where bacteriological and mycological protocols are applied. ${ }^{30}$

\section{Quality testing Microbiological testing}

The guide to the quality and safety of tissues and cells for human application suggests that microbiological testing for bacterial and fungal contamination follows standardized protocols (Table 1). ${ }^{24}$

\section{Bacteria}

In our skin bank, a skin sample is defined as "negative" for microbial contamination if absence of bacterial growth is observed after 3 and 7 days in aerobic and anaerobic cultures. A culture is defined as "positive" if a single bacterial colony-forming unit is identified to genus and species level by means of selective media and semiautomatic biochemical tests (e.g., ATB BioMerieux). Slow-growing bacteria (e.g., mycobacteria) are identified by polymerase chain reaction (i.e., 16S rRNA sequencing). Antibiograms are performed in the case of positive results. ${ }^{15-32}$ According to a recent study by Pirnay et al, ${ }^{32}$ an incubation time of 14 days allows an additional $16.9 \%$ of contaminated skin to be detected compared with the traditional 3-day incubation protocol. The authors also noted that $24 \%$ of the slow-growing bacteria detected after 14 days could be considered potentially pathogenic. $^{32}$

\section{Yeasts and fungi}

Samples are incubated in Sabouraud agar with chloramphenicol at $+30^{\circ} \mathrm{C}$ in air for 21 days to detect fast-, medium- and slow-growing mycetes. According to the protocol, the sample is declared negative if no growth of yeast or fungi is observed after 21 days. The genus and species of any yeast colonies are determined by selective chromogenic substrates (e.g., ChromAgar and Sabouraud cycloheximide agar, BioMerieux) and semiautomatic biochemical tests (e.g., ATB-BioMerieux). When filamentous colonies grow, staining with lactophenol cotton blue or slide culture is usually performed, then identification by microscope observation. ${ }^{15-28}$

\section{Additional tests}

Besides microbiological tests for fast- and slow-growing aerobic and anaerobic bacteria and fungi performed on tissue by 3-week culture, further quality controls are required to ensure that tissues are processed aseptically, and also to demonstrate that the processing operators and/or environment are not possible sources of contamination..$^{21,23,30}$ These controls further include particle counts and microbiological analysis in the laboratory, microbiological analysis of processing media and operators (glove prints). ${ }^{31,32}$

\section{Skin discard}

The contamination rate is the proportion of skin samples not released from quarantine due to bacterial or fungal contamination at different steps of procurement or processing. The discard rate expresses the percentage of discarded skin donors on all skin donors procured in 1 year. Only critically contaminated skin allografts were discarded (e.g., polyresistant bacteria). Skin allografts contaminated by nonpathogenic agents (e.g., Staphylococcus epidermidis, Staphylococcus capitis and Propionibacterium acnes) can be reprocessed by glycerolization; ${ }^{30}$ antibiotics are selected on the basis of antibiograms, and those negative after reprocessing can be issued for further use. In 2016, in our skin bank, 25/132 (19.3\%) donors appeared to be contaminated by nonpathogenic bacteria (after reprocessing by glycerolization recovery procedure, the final discard rate for multiresistant contaminated allografts was 3/132 [2.3\%]).

Similarly, in 2012, the Brussels military skin bank validated a glycerolization-based recovery method that allowed effective inactivation of colonizing agents such as bacteria and fungi, excluding spore-formers, and did not modify skin allograft structure and function. ${ }^{29}$ When recovery procedures were performed, the discard rate was less than the contamination rate. Before long-term storage, skin and DED grafts are always tested for sterility. ${ }^{31}$

\section{Viability assessment}

\section{The cell viability debate}

There is an ongoing debate on the importance of cell viability for skin allograft efficacy as a skin substitute. It is traditionally accepted that viable cryopreserved skin allografts (CSAs) 
are superior to other dressing bioproducts. From their experience with burns, difficult wounds and leg ulcers, various authors agree that higher viability is associated with better wound-bed preparation and graft taking..$^{13,17,33-35}$ Viable CSAs are deemed to have better transplant performance, to promote neovascularization, speed up healing, stimulate immunomodulatory response and reduce mortality risk. ${ }^{13,14,31-36}$ Some authors speculate that high cell viability may not be necessary for skin allograft function as a temporary dressing or permanent substitute. ${ }^{37,38}$ However, comparison of viable CSAs with unviable glycerol-preserved allografts (GPAs) has shown superior clinical outcomes (e.g., lower mortality and morbidity rate, reduced healing time) in both adult and child burn patients treated with viable CSAs. ${ }^{13,29,35}$ In our experience, CSAs stimulate wound-bed granulation in burns, hard-to-heal wounds and venous ulcers better and more rapidly than glycerolized nonviable skin. However, this assumption comes largely from direct observation and clinical experience, since large-scale standardized studies on whether CSAs are clinically superior to GPAs are yet to be performed. ${ }^{36}$

\section{Assessment of cell viability: state of the art}

It is important for a skin bank to assess and certify the viability of CSAs before transplantation. ${ }^{13,15,16,27,30,36}$ However, three main problems are encountered. First, tissue viability is difficult to measure in the laboratory: since in vivo setting conditions are very different, laboratory tests cannot achieve $100 \%$ accuracy. Second, since different skin viability assessment methods, both quantitative (e.g., glucose or oxygen consumption assay, vital staining methods, lactate production, etc.) and qualitative (e.g., cell count by trypan blue test) are used, ${ }^{36-38}$ and they cannot be compared. Third, because different authors have developed their own formulae to calculate skin viability, study results cannot always be compared. ${ }^{14,17,33-35,38,39}$ It will therefore be necessary to harmonize laboratory methods and standardize viability testing and measurement in order to compare study results. ${ }^{36}$

\section{Siena skin bank viability testing method}

At the Siena skin bank, the trypan blue test and cell culture tests are not performed as routine viability tests, because appropriate evaluation showed that this procedure is unreliable, time consuming and expensive. ${ }^{36}$ The MTT metabolic assay is preferred as it has proven reliable and reproducible, and is widely used for cell viability assessment in most skin banks. ${ }^{29,33,36,38}$
The MTT metabolic assay (based on 3-(4,5-dimethylthiazol-2-yl)-2,5-diphenyltetrazolium bromide) relies on reduction of water-soluble tetrazolium salts to insoluble formazan pigments by mitochondrial enzymes. The pigment produced is dissolved and extracted with an organic solvent and quantified spectrophotometrically, measuring extractant optical density (OD) at a wavelength of $570 \mathrm{~nm}$. Histology performed after the MTT test has demonstrated pigment fixation only in the epidermal layers (Figure 4).

Based on our past experience with cell viability measurements, ${ }^{7,30,31,28}$ we elaborated a corrected formula to express CSA cell viability, excluding other confounding factors (i.e., weight and area of the sample procured from the skin graft, $\mathrm{mL}$ of solvent, skin normalization to $100 \%$ ) and detecting OD at $570 \mathrm{~nm} .{ }^{29} \mathrm{We}$ propose that expressing viability in terms of corrected OD $(570 \mathrm{~nm})$ (corr OD570 $\mathrm{nm}=$ OD positive control - OD negative control) could be more appropriate and closer to real data. ${ }^{36}$

\section{Storage methods}

Two common methods of skin allograft preservation are glycero-preservation and cryopreservation. The main difference between the two techniques lies in tissue viability: glycerolized and lyophilized skin grafts are not viable but retain structural and mechanical properties, whereas cell viability is maintained by cryopreserved, and to a lesser degree deep frozen, skin grafts, so the tissue can be grafted onto a wound bed after a certain period of time..$^{13,35-38}$ The ongoing debate concerning the clinical advantages of GPAs or CSAs/ frozen skin allografts is related to this basic difference. ${ }^{35,37,39}$

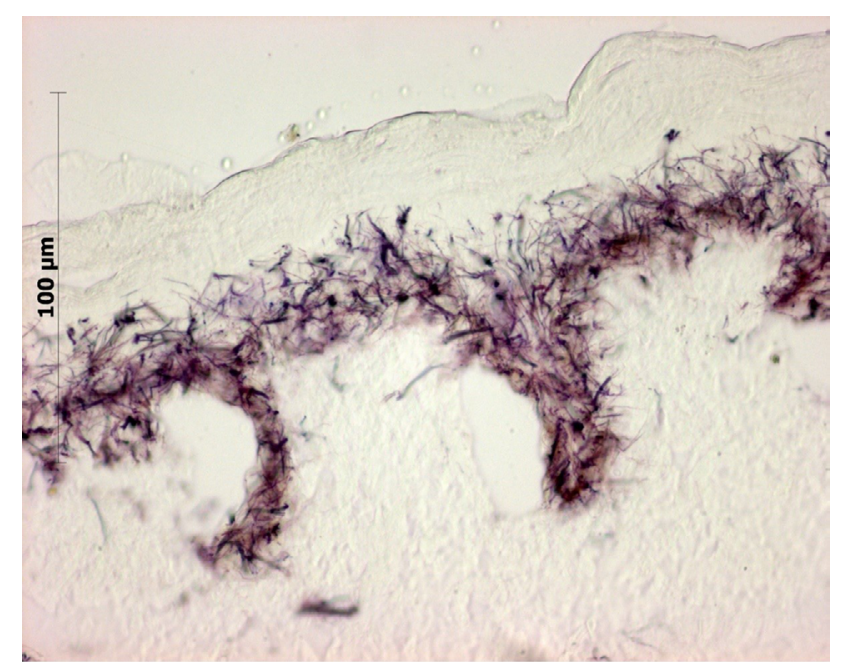

Figure 4 Histological study showing cryostat tissue sections of skin allograft samples after MTT assay: the purple formazan pigment marks viable cells and is limited to the epidermal layers. 
Table 2 Overview of current storage methods

\begin{tabular}{ll}
\hline Storage method & Description \\
\hline Freeze-drying (lyophilization) & $\begin{array}{l}\text { Dehydration process by freezing the material and then reducing the surrounding pressure to allow } \\
\text { the frozen water in the material to sublimate directly from the solid phase to the gas phase. Residual } \\
\text { moisture in tissues: } 1 \%-6 \%\end{array}$ \\
Freezing/deep freezing & Storage between $-15^{\circ} \mathrm{C}$ and $-80^{\circ} \mathrm{C}$ with cryoprotectant solutions \\
Cryopreservation & Storage at $<-135^{\circ} \mathrm{C}$ in liquid- or vapor- phase nitrogen, with cryoprotectant solutions \\
Glyceropreservation & Storage at $2^{\circ} \mathrm{C}-8^{\circ} \mathrm{C}$ in high-percentage glycerol solution \\
Drying & Tissue dried at room temperature and low humidity atmosphere \\
Alcoholic preservation & Storage in ethanol (about $96 \%)$ \\
Cell culture medium preservation & Preservation in a growth medium for viable tissues and cells
\end{tabular}

Note: Data from www.eurocode.org. ${ }^{68}$

Other recently developed types of preservation of unviable tissue are lyophilization and gamma-irradiation, with the advantages of extended storage and sterility, respectively (Tables 2 and 3). ${ }^{36,40-43}$

\section{Cryopreservation and freezing}

CSAs were first introduced into clinical practice in 1979 to treat severe burns. ${ }^{5,6}$ Cryopreservation is defined as a process in which the biological and structural functions of tissues or cells are preserved by cooling to subzero temperatures in a cryoprotectant such as dimethyl sulfoxide or glycerol (Table 3). Cryopreservation of skin allografts requires rapid processing phases at low temperature to maintain sufficient cell viability. Inappropriate storage can impair the normal metabolic activity of skin and, therefore, all its physiological functions after transplantation.

Skin samples are usually processed within $72 \mathrm{~h}$ of reception. Soaking in antibiotic or antimicrobial solutions is widely used to decontaminate viable tissues that cannot be terminally sterilized..$^{36,39-43}$ To maintain cell integrity and tissue structure, skin grafts should be incubated in cryoprotectants, cooled gradually and thawed rapidly when needed for clinical use. ${ }^{44-46}$ Cryopreserved skin grafts are stored at $-130^{\circ} \mathrm{C}$ in vapor-phase nitrogen or at $-196^{\circ} \mathrm{C}$ in liquid nitrogen.

Frozen (with storage at $-15^{\circ} \mathrm{C}$ ) and deep-frozen allografts stored at $-80^{\circ} \mathrm{C} /-60^{\circ} \mathrm{C}$ are also viable skin grafts but with reduced cell viability. The storage time (i.e., months or years) should be validated and included in skin bank procedures (Tables 2 and 3).

Tissue morphology and integrity should be assessed by histomorphology and/or immunochemistry. At the Siena skin bank, routine histological observations on CSAs/ frozen allografts after 15 days of storage have not shown any substantial alterations in the stratum corneum, in the integrity of the epidermal layers or in the dermo-epidermal junction; fibroblasts are still observed in the dermis (Figure 5). Freeze-induced histological alterations (i.e.,
Table 3 Temperature range for storage of tissues and: updated terminology

\begin{tabular}{ll}
\hline Storage condition & Temperature limits $\left({ }^{\circ} \mathrm{C}\right)$ \\
\hline Cryopreserved (vapor phase or & $<-135^{\circ} \mathrm{C}$ \\
liquid nitrogen) & $-80^{\circ} \mathrm{C}$ to $-60^{\circ} \mathrm{C}$ \\
deep frozen & $<-15^{\circ} \mathrm{C}$ \\
Frozen & $2^{\circ} \mathrm{C}$ to $8^{\circ} \mathrm{C}$ \\
Refrigerated & $8^{\circ} \mathrm{C}$ to $15^{\circ} \mathrm{C}$ \\
Cold or cooled & $15^{\circ} \mathrm{C}$ to $25^{\circ} \mathrm{C}$ \\
Room temperature & \\
\hline
\end{tabular}

Note: Data from European Directorate for the Quality of Medicines \& HealthCare (EDQM). Guide to the quality and safety of tissues and cells for human application. France: EDQM; $2015 .{ }^{24}$

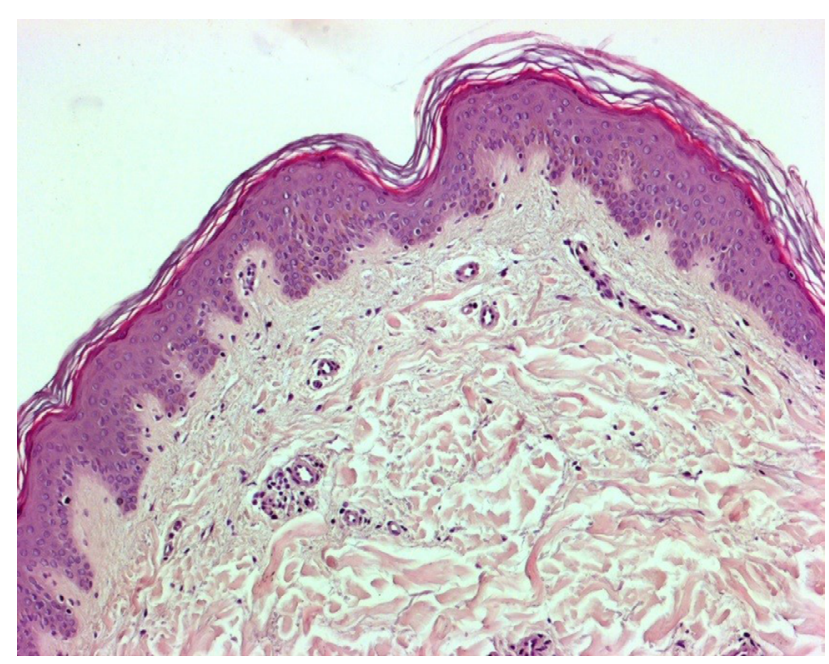

Figure 5 Skin allograft histopathologic study (hematoxylin and eosin staining) after 15 days of storage at $-80^{\circ} \mathrm{C}$ (original magnification 100x): morphology of skin layers is preserved.

epidermal-dermal separation, fragmentation of collagen and elastic fibers) are rarely encountered. Separation of the stratum corneum from the epidermis is only observed when the interval between procurement and storage exceeds $48 \mathrm{~h}^{36}$

\section{Storage temperature}

At our skin bank, freezing is performed with a single-stage protocol in a slow freezer (such as a Planer-Kryosave 
Integra) at $-1^{\circ} \mathrm{C}$ to $-2^{\circ} \mathrm{C}$ per min from $+10^{\circ} \mathrm{C}$ to $-90^{\circ} \mathrm{C} .36,44$ Our median storage period before utilization of CSAs is 1-2 months.

Other authors use a three-step preservation procedure, freezing the skin tissue to $-20^{\circ} \mathrm{C}$ in the first hour, holding it at $-80^{\circ} \mathrm{C}$ for at least $24 \mathrm{~h}$ and then storing it in liquid nitrogen at $-130^{\circ} \mathrm{C}$ or below until use..$^{33,44}$ For allografts subject to long-term cryopreservation, many authors prefer storage below $-130^{\circ} \mathrm{C}$ to avoid ice crystal formation and cell damage. ${ }^{45,46}$ Typical temperatures are $-135^{\circ} \mathrm{C},{ }^{47}-150^{\circ} \mathrm{C}$ and $-170^{\circ} \mathrm{C}^{18,37,48}$

\section{Storage temperature and allograft viability}

It is commonly accepted that storage temperature has an impact on cell viability. ${ }^{43-49}$ In general, the decay of cell viability is inversely correlated with storage time and depends on storage temperature. Most authors agree that acceptable viability is obtained with a storage temperature of $-80^{\circ} \mathrm{C}$ or below $\left(-130^{\circ} \mathrm{C}\right)$. Indeed, storage of tissues at $+4^{\circ} \mathrm{C}$ had shown to reduce viability in a few weeks. ${ }^{15,18,47,49}$ Similar results were observed with storage at $-70^{\circ} \mathrm{C} .{ }^{46,50}$ Most studies have investigated the viability of skin allografts cryopreserved for 2 and 4 weeks: very few have focused on long-term storage ( $\geq 2$ months). ${ }^{36,51,52}$

\section{Short-term storage studies}

After 2 weeks of storage at $-80^{\circ} \mathrm{C}$, using the three-step freezing, some authors reported a cell viability decay of $50 \%{ }^{14,33,43}$ Castagnoli et al showed that preservation at $-80^{\circ} \mathrm{C}$ gives constant results (i.e., 50\% loss of cell viability), suggesting that the final viability largely depends on the length of the prefreezing period, irrespective of initial values. ${ }^{33} \mathrm{We}$ observed similar results after 2 weeks at $-80^{\circ} \mathrm{C}$ with the one-step freezing protocol (i.e., a median reduction in cell viability of $50 \%$, range $19 \%-81 \%$ ) with the MTT assay. ${ }^{36}$

\section{Long-term storage studies}

In 1989, De Luca et al found a colony-forming efficiency of $45 \%-50 \%$ in cryopreserved cultured human epithelial grafts stored at $-80^{\circ} \mathrm{C}$ for over 2 months. ${ }^{51}$ In 1990 , Teepe et al estimated a cell viability of $62.8 \%$ by the dye exclusion method (trypan blue) in cryopreserved cultured epithelial grafts stored for 6 weeks at $-70^{\circ} \mathrm{C} .{ }^{52}$ More recently, Udoh et al compared cell viability measures of CPAs stored at $-135^{\circ} \mathrm{C}$ and $-80^{\circ} \mathrm{C}$ : median cell survival rates were $89.3 \%, 61.7 \%$ and $61.6 \%$ after 1,6 and 12 months of storage at $-135^{\circ} \mathrm{C}$, respectively, whereas at $-80^{\circ} \mathrm{C}$, survival rates were much lower (35.2\% viability after 6 months). ${ }^{48}$ Colony-forming efficiency of grafts cryopreserved for 1, 6 and 12 months was estimated at $66.1 \%, 58.5 \%$ and $55.1 \%$, respectively, of noncryopreserved control grafts. Some histological differences between the two groups were also reported: epidermal structure was maintained after 6 months of storage at $-135^{\circ} \mathrm{C}$, but not at $-80^{\circ} \mathrm{C} .{ }^{48}$

In 2013 , Schiozer et al estimated viability at $37 \%, 25 \%$ and $15 \%$ of the original values after 1,6 and 12 months, respectively, at $-70^{\circ} \mathrm{C}$ : these values were estimated by the trypan blue viability assay and metabolic analysis based on glucose consumption and lactate production. ${ }^{46}$

In our experience with the MTT assay, the greatest loss in viability occurred in the first 15 days of storage. Indeed, loss of cell viability was $54.4 \%, 65 \%$ and $69 \%$ after 15 days, 6 and 12 months, respectively, compared with fresh skin (prefreezing). In addition, loss of viability was 23\% after 6 months and $33 \%$ after 12 months compared with viability after 15 days of storage.

Finally, we recently reported that besides depending on freezing protocol, storage temperature and/or period, final cell viability is primarily influenced by the initial viability of the fresh sample, which is likely to depend on donor clinical and medical data, such as age, sex and cause of death. ${ }^{36}$

\section{Glycero-preservation}

Preservation through glycerolization was introduced by the Euro Skin Bank in 1984 and involves incubation in increasing concentrations of glycerol solution in order to fix free water in intra- and extracellular spaces. ${ }^{52-54}$ GPAs are maintained at a temperature of $+2^{\circ} \mathrm{C}$ to $+10^{\circ} \mathrm{C}$ in concentrated glycerol solution. It is recommended to expose allografts to $98 \%$ glycerol for at least 4 weeks before clinical use to increase their safety. ${ }^{53,54}$ Glycero-preserved skin allografts are nonviable grafts, as the process of glycerolization destroys vital structures (Table 2). Although no previous studies have identified glycerolization-induced alterations in human skin allografts, the effects of this treatment on other connective tissues, including mechanical and structural changes, suggest that the skin may also be affected. ${ }^{56}$ Indeed, glycerolization has been found to increase the stiffness of human sclera with no visible change to the connective tissue matrix. ${ }^{57}$

Glycero-preservation has some advantages as GPAs have a certain degree of antibacterial and antiviral activities as well as reduced immunogenicity; processing is simpler than for cryopreservation, and grafts are easily distributed at refrigerated temperature. Thus, GPAs are widely used in clinical practice all over the world as temporary dressing, alone or combined 
with CSAs, for difficult, posttraumatic and surgical wounds, and deep loss of substance (e.g., tendon coverage). ${ }^{58-60}$ To treat burn patients, most centers generally prefer CSAs. In very old or young severe burn patients and/or in burns with minimal morbidity, some authors make strategic use of GPAs; for example, GPAs can be used not only for wound-bed preparation but also in sandwich grafting or as a dressing for partial-thickness burns. ${ }^{35,54-60}$ Indeed, it is traditionally believed that GPAs have antimicrobial properties and limit bacterial invasion and proliferation in the wound bed by acting as a mechanical barrier, possible bacterial contamination. ${ }^{54-61}$

\section{Gamma-irradiation}

Sterilizing tissue grafts offer a clear advantage in terms of safety and do not pose any environmental concerns. Therefore, radiation sterilization has become the method of choice for an increasing number of tissue banks, especially for musculoskeletal grafts. Gamma-irradiation is the process of exposure to gamma rays from radionuclide isotopes $60 \mathrm{Co}$ and $137 \mathrm{Cs}$. According to the International Atomic Energy Agency, a radiation dose of $25 \mathrm{kGy}$ is defined as the reference dose for the sterilization of the tissue grafts, but some tissue banks prefer lower radiation dose (e.g., $15 \mathrm{~Gy}$ ) to respect tissue properties. Adequate radioprotectant agent must be used in a pre-irradiation treatment. ${ }^{62}$ As per the skin tissue, gamma-irradiation was not considered a possible sterilization methods until 10 years ago. Some authors reported toxic or architectural alterations such as increased tissue stiffness induced by free radicals cross-linking collagen fibers of $25 \mathrm{kGy}$. Rooney et al found that irradiation with $25 \mathrm{kGy}$ of deep-frozen skin soaked in low glycerol concentration (i.e., $20 \%$ ) prior to irradiation is not harmful to tissue structure. ${ }^{63}$

\section{Lyophilization/freeze-drying}

Lyophilization (freeze-drying or cryodesiccation) is a dehydration process involving two consecutive steps: a freezing phase and a sublimation phase, in which low pressure allows frozen water to sublimate directly from a solid to a gaseous state. This processing technique is generally applied to dermal matrices. ${ }^{58}$ Briefly, skin is de-epidermized and processed for decellularization, which commonly consists of physical, biological (enzymatic) and chemical methods, variously combined. ${ }^{41,43,56-65}$ Such freeze-dried acellular dermis lacks immunogenic potential and is sterile, and can therefore be used as a dermal scaffold that integrates into the host tissue or closed wounds. It is easily stored and distributed, and is used when required after re-hydration (for $30-60 \mathrm{~min}$ at $+37^{\circ} \mathrm{C}$ in sterile saline in the case of lyophilized dermis).

\section{Our experience}

The acellular DED that we routinely produce in our skin bank undergoes the following steps: incubation with detergents, sonication, washing, incubation in cryoprotectant solution (i.e., Clearant ${ }^{\mathrm{TM}}$ ) and $\gamma$-ray irradiation with $25 \mathrm{kGy}$ from a Co-60 source. Its non-viability is confirmed by immunohistochemical data, such as negative viability according to Ki67 and MIB-1 tests. Acellular lyophilized $\gamma$-irradiated DED maintains its original structure, with optical and transmission electron microscope evidence of integral elastic and collagen fibers ${ }^{66}$ (Figure 6A). In vitro biocompatibility tests (cytotoxicity tests with fibroblasts and cultured keratinocytes) demonstrate that the product does not inhibit cell growth or colonization of host cells on its surface (Figure 6B). Mechanical stress tests also demonstrate that its elastic performance is equivalent to that of untreated dermis. ${ }^{66}$

\section{Clinical use of skin bank bioproducts Clinical use of skin allografts: history}

The first report of skin grafting dates back to the second century BC, when the Indian surgeon Sushruta used auto-grafted skin for rhinoplasty. ${ }^{67}$ The Swiss surgeon Reverdin was the first to use skin allografts to treat wounds: he described an autologous allografting method and in 1869 developed a method known as the "pinch grafting" technique. In 1870 , George Lawson proposed a deeper-thickness graft, including epidermis and reticular dermis. ${ }^{68}$ Five years later, the German surgeon Thiersch described skin graft adherence to a wound bed by histological research. His experience on a limited group of patients treated with partial-thickness combined allografts (epidermis and a variable quantity of dermis) was published in 1875. However, he encountered problems with re-epithelization of donor sites when harvesting partial-thickness autografts: this oriented the preference for thin grafts in subsequent years. ${ }^{69}$ In 1881, Girdner started to systematically employ autologous skin grafts for burns and wounds. ${ }^{67,70} \mathrm{He}$ also tried to use allografts: he procured skin
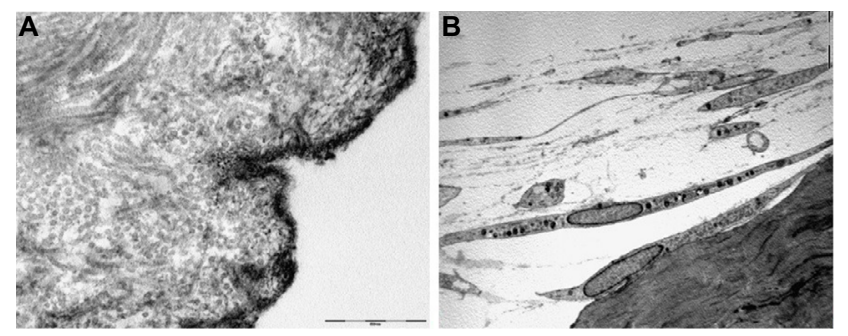

Figure 6 Electron transmission microscopy showing preserved the architectural structure of the dermis, integrity of the basal membrane and skin polarization (A). Histocompatibility test with human fibroblasts, colonizing the dermal surface (B). 
from the thigh of a young German boy and transplanted it to a 10 -year-old burn patient.

In the first decades of the twentieth century, several wellknown investigators established the inevitability of allograft failure. Georg Schöne determined that allograft always failed, and subsequent grafts from the same donor failed more rapidly (1912). ${ }^{67,69,70}$ Peter Medawar (1915-1987) was the first to successfully use homologous skin grafting, for which he received the Nobel Prize in 1960. He gained experience with severe burn patients in London during World War II and conducted extensive studies on skin allograft, defining the timing and the histological and immunological characteristics of rejection. He also hypothesized that skin grafts between twins would only be accepted by identical twins. ${ }^{70}$

In the past 50 years, the clinical experience of surgeons and physicians has advanced the use of skin allografts for the treatment of burns. On the one hand, it was noted that the dermal layer was the principal actor of skin allografting, representing a resilient and tough new surface. On the other hand, it was observed that donor-site epithelium regenerated from deep epithelial islands within hair follicles and sebaceous glands after removal of partial-thickness grafts; thicker grafts could therefore be harvested, and transfer of the upper dermis would not interfere with donor-site healing. Moreover, new instruments for skin procurement allowed these thicker grafts to be obtained. Further technical advances offered a wider range of therapeutic choices in the treatment of burns, and methods such as pinch grafts (Thiersch technique) and pedicle flaps are now considered obsolete. ${ }^{68-70}$

\section{Skin allograft classification}

Skin grafts can be classified according to their thickness (Figure 7) or indicated by the name of the physician who first developed the technique (Table 4).
Table 4 Classification of skin allografts according to their thickness

\begin{tabular}{lll}
\hline Type & Characteristics & Thickness, $\mathbf{m m}$ \\
\hline Split thickness & Thin (Thiersch-Ollier) & $0.15-0.3$ \\
& Intermediate (Blair-Brown) & $0.3-0.45$ \\
Full thickness & Thick (Padgett) & $0.45-0.6$ \\
& Thick (Wolfe-Krause) & $>0.6$ \\
\hline
\end{tabular}

A split-thickness skin graft is a skin graft that includes the epidermis and part of the dermis. The thickness of the graft depends on the donor site, and the clinical purpose: splitthickness grafts are usually employed to cover large areas. The rate of autorejection is low. The area of the skin graft can be expanded to 9 times its size using a specific skin mesher. The donor site heals by re-epithelialization from the dermis and surrounding skin: appropriate dressings speed up the process so that the same site can, if necessary, be harvested again after 6 weeks.

A full-thickness skin graft consists of the epidermis and all of the dermis. The donor site is either sutured closed directly or covered by a split-thickness skin graft.

A composite graft is a graft containing skin and underlying cartilage or other tissue. Donor sites may, for example, include ear skin and cartilage to reconstruct nasal ala rim defects. $^{71}$

\section{Skin and dermal allograft advantages for clinical use}

The gold standard to obtain permanent wound closure is autologous grafting: however, autografting is only possible in a minority of cases. In all other patients, allografting is often the best alternative. The use of human skin allografts has several advantages, including reduction of water, elec-

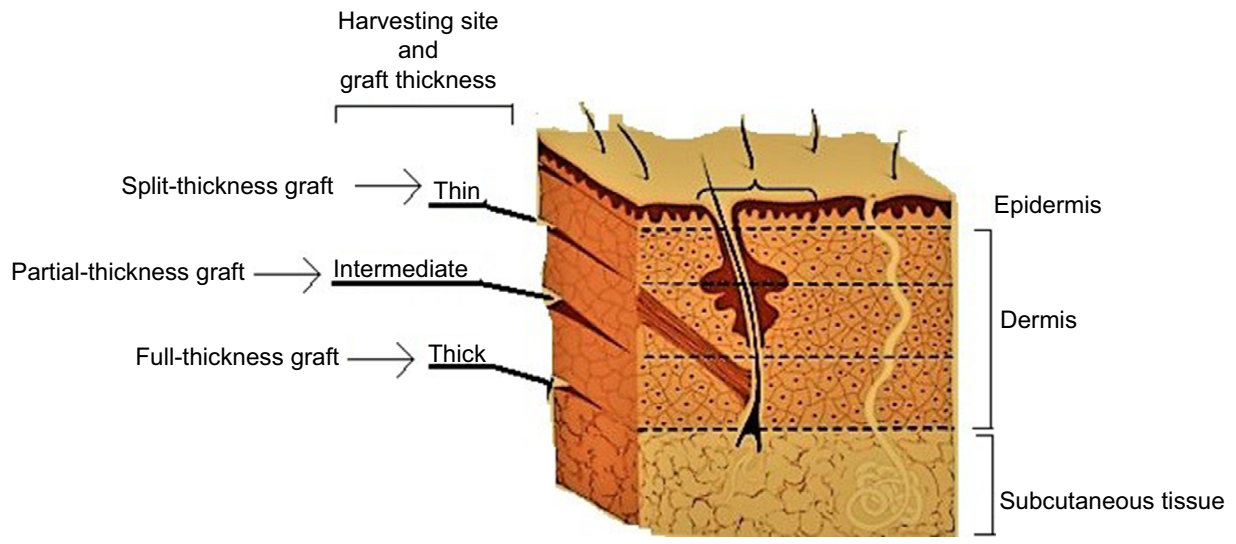

Figure 7 Classification of skin allografts according to their thickness and site of dermatome cleavage. 
Table 5 Indication of skin bank bioproducts: classification and clinical use

\begin{tabular}{|c|c|c|c|c|}
\hline Cryopreserved skin & $\begin{array}{l}\text { Cryopreserved } \\
\text { DED }\end{array}$ & $\begin{array}{l}\text { Glycero- } \\
\text { preserved skin }\end{array}$ & $\begin{array}{l}\text { Glycero-preserved/ } \\
\text { dermis/DED }\end{array}$ & $\begin{array}{l}\text { Lyophilized acellular } \\
\text { dermis }\end{array}$ \\
\hline Cell viability & & \multicolumn{3}{|l|}{ Nonviable tissue } \\
\hline \multicolumn{2}{|l|}{ Wound-bed preparation, skin regeneration } & \multicolumn{3}{|c|}{ (GPskin) antalgic effect, scaffold for skin regeneration } \\
\hline $\begin{array}{l}\text { Composite graft, temporary coverage, } \\
\text { possible engraftment of the dermal } \\
\text { component }\end{array}$ & $\begin{array}{l}\text { Composite graft, } \\
\text { temporary coverage }\end{array}$ & $\begin{array}{l}\text { Temporary } \\
\text { coverage, } \\
\text { composite graft }\end{array}$ & $\begin{array}{l}\text { Composite graft, } \\
\text { possible engraftment of } \\
\text { the dermal matrix }\end{array}$ & $\begin{array}{l}\text { Engraftment of the dermal } \\
\text { matrix }\end{array}$ \\
\hline Extensive burns & Posttraumatic wounds & Extensive burns, & Pressure/posttraumatic & Cutaneous full-thickness \\
\hline Nonhealing leg ulcers & Leg ulcers & cutaneous & wounds/ulcers & wounds (venous ulcers, \\
\hline Epidermolytic diseases & & wounds, & Full-thickness burns & pressure ulcers, diabetic/ \\
\hline (Stevens-Johnson syndrome) & & Lyell syndrome & cutaneous wounds & trophic ulcers) \\
\hline - Toxic epidermal necrolysis & & Extensive ulcers & & Burns (hot, chemical), surgery \\
\hline - Staphylococcal scalded skin syndrome & & Donor area & & (posttraumatic full-thickness \\
\hline Posttraumatic/surgical wound & & coverage & & wounds), orthopedic surgery, \\
\hline regeneration & & & & ENT, oral and plastic surgery \\
\hline
\end{tabular}

Note: Data from Fimiani et al. ${ }^{74}$

Abbreviations: DED, de-epidermized dermis; ENT, ear nose and throat.

trolyte and protein loss, and antibacterial effect, wound pain reduction (especially glycerolized skin allografts), preparation of wound bed for definitive closure, promotion of epithelialization and provision of dermal templates for epidermal grafts.

Hence, indications for skin allografts in wound management include coverage of extensive wounds where autologous tissue is not available, coverage of widely meshed skin autografts, extensive partial-thickness burns and extensive epidermal detachment. Using dermal allografts is of main importance in the management of wound healing, as the less immunogenic dermal component takes to the wound bed (Table 5).

\section{Techniques for clinical use of skin and dermal allografts}

Split-thickness grafts are indicated for covering large areas. Several combinations can be adopted, according to the depth and type of wound, including: cryopreserved/glyceropreserved skin or dermis; mono or multi-layer; meshed (i.e., expanded) or unmeshed skin/dermis; combination of allografts with autografts. ${ }^{72}$

\section{Unmeshed allografts}

Allogeneic grafts are best applied unmeshed (or minimally expanded) to maximize their ability to temporarily close the wound (Figure 8). Fresh allografts, and to a lesser extent cryopreserved allografts, become well vascularized, stimulate neovascularization in the underlying wound bed, and prepare the recipient sites for permanent coverage with autologous skin. In addition, viable allografts tolerate modest wound

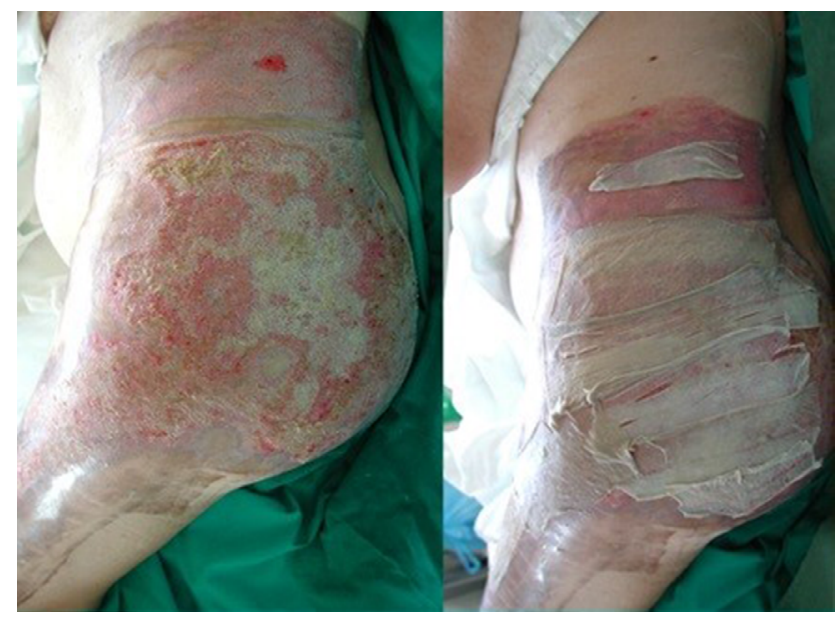

Figure 8 Unmeshed cryopreserved allografts coverage of burned skin area.

contamination and adhere better to the freshly excised subcutaneous fat than do cryopreserved grafts. Allogeneic skin is usually removed once the patient donor sites have healed sufficiently for reharvesting or once autologous cultured skin is available for permanent wound closure. Unmeshed cryopreserved skin allografts can be employed in burns, hard-to-heal wounds and ulcers (Figure 9). Cryopreserved skin allografts show delayed rejection in severe burns due to immunocompromised conditions and can last on the wound several weeks before rejection.

\section{Meshed and combined allografts}

To cover large burn areas involving $\geq 50 \%$ of the total body surface area, when autologous skin cannot be procured, meshed allografts at different expansion rates (e.g., 3:1, 4:1 and 6:1) can be used (Figure 10). In cases of extensive full- 
thickness injury, the meshed autologous graft can be further used and protected by meshed or unmeshed skin allografts to obtain re-epithelization. Alexander ${ }^{72}$ first described the use of meshed widely expanded autologous skin grafts covered with meshed allografts having a lower expansion rate

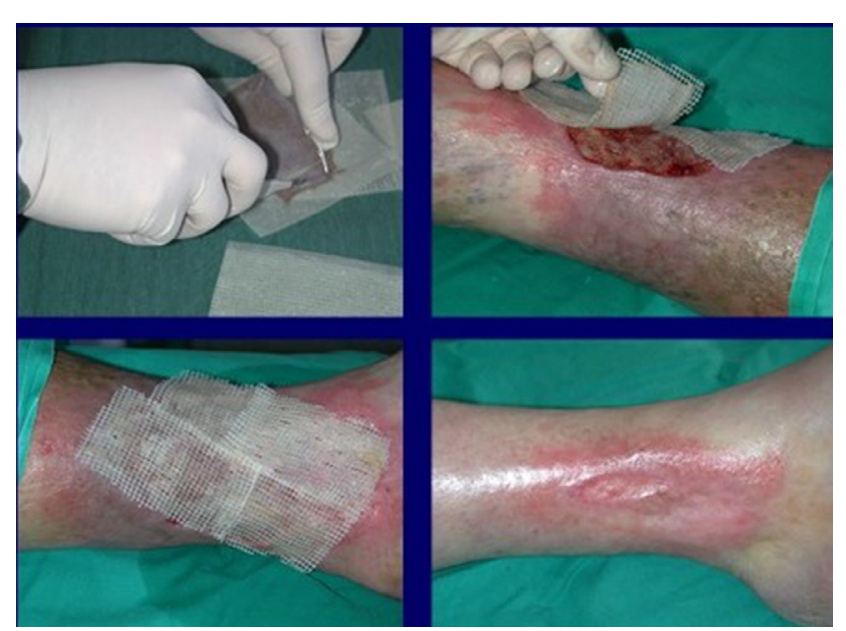

Figure 9 Treatment of a leg ulcer wound with cryopreserved unmeshed skin allografts.
(Figure 11A). Surgeons/physicians can select the expansion rate and directly mesh skin/dermis according to the case (Figure 11B). This method provides immediate as well as temporary and permanent wound closure. However, in less extensive wounds, many surgeons have expressed concern that the overlying allograft may induce inflammatory rejection that can delay the taking of the underlying autografts. In such cases, the use of acellular dermal matrices (less antigenic) may be preferred. ${ }^{73,75,76}$

Meshed cryopreserved/frozen de-epidermized dermis can sometimes be integrated into the wound bed of full-thickness burns or leg ulcers (Figure 12A and 12B). Otherwise, in cases of deep wounds with tendon exposure, meshed glycerolized (Figure 13) or lyophilized (Figure 14) allodermis can be applied to protect delicate structures, and then covered with skin allografts.

\section{Conclusion}

Skin allografts are deemed effective in the treatment of many kinds of skin loss and may be life-saving. They have important clinical uses, behaving as physiological medication,
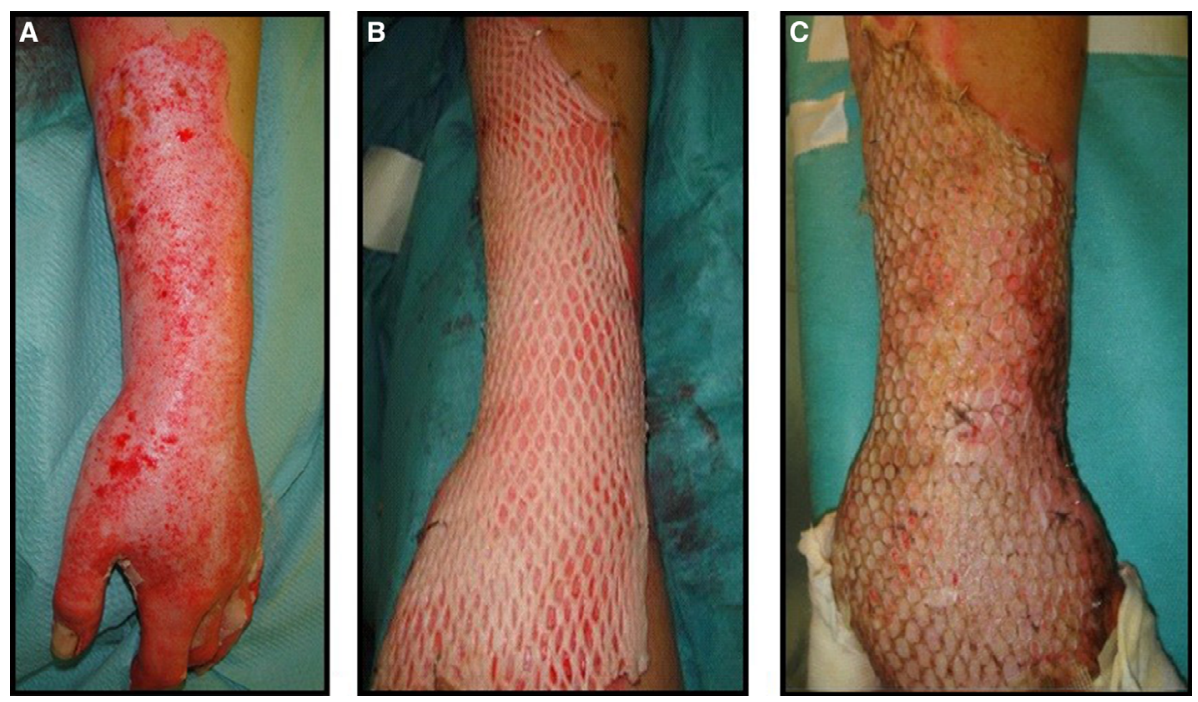

Figure 10 Autologous cryoreserved skin allografts meshed 3:I used to cover a burn injury.

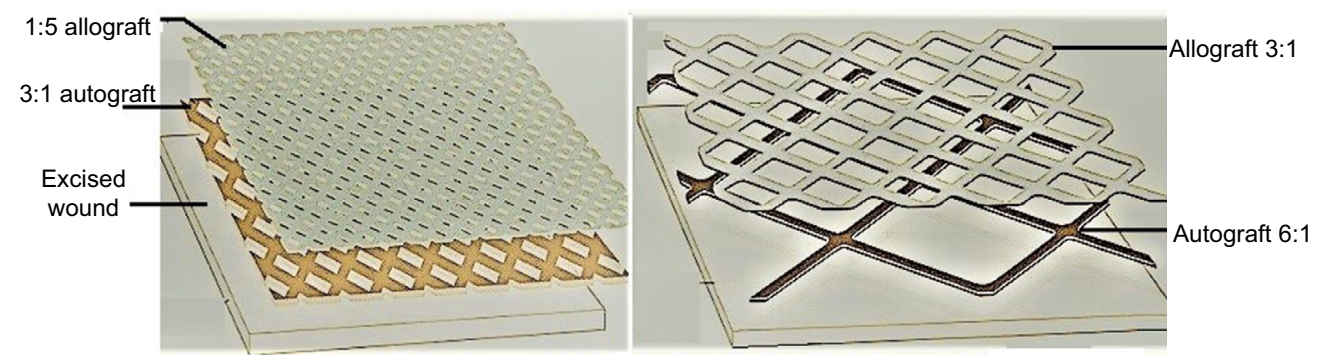

Figure II “Alexander” original technique: meshed allograft overlay of an underlying meshed autograft (A). "Sandwich technique”, variant of "Alexander” original technique (B). 

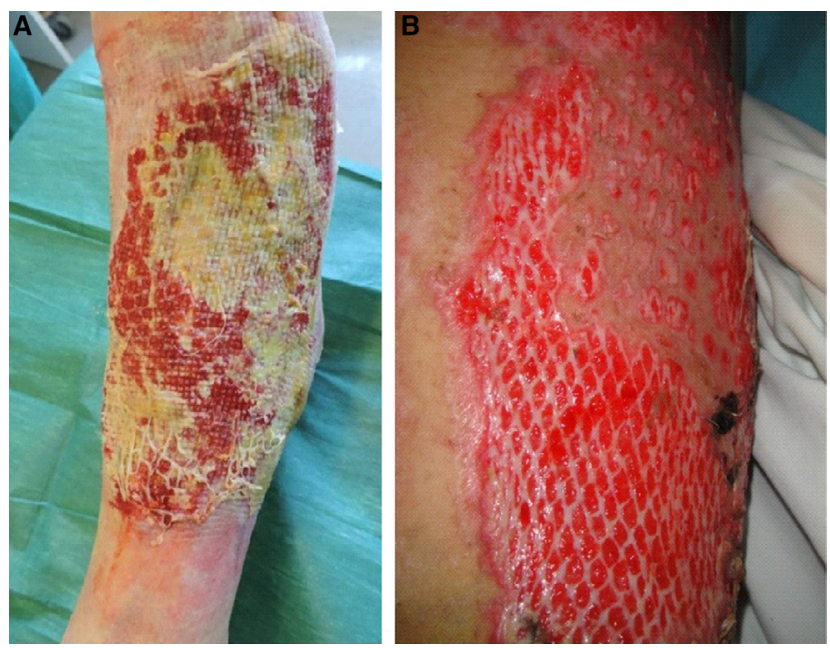

Figure 12 Cryopreserved meshed de-epidermized dermis integration onto the wound bed of a leg ulcer (A) and a full-thickness burn (B).
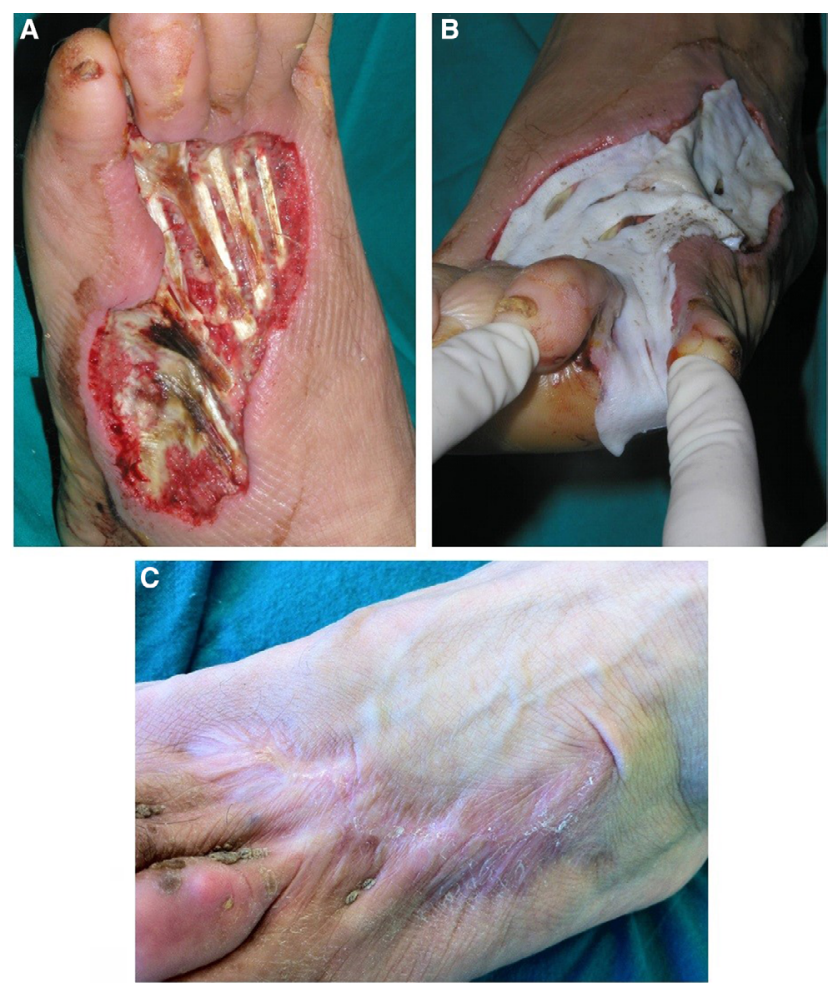

Figure 13 Coverage of tendons exposure and dermal component reconstruction in a deep traumatic wound by glycerolized dermis. Wound appearance after adequate debridement (A), application of glycerolized DED (B), and final re-epithelization after 2 months (C).

Abbreviation: DED, de-epidermized dermis.

promoting wound healing, shortening hospitalization time, controlling pain and protecting dermal and subcutaneous structures (cartilage, tendons, nerves and bones). They are also successfully used as skin substitutes that incorporate the dermal component into the wound bed, guiding a more physiological healing process. Although a great variety of synthetic and semisynthetic dermal matrices and skin equivalents are
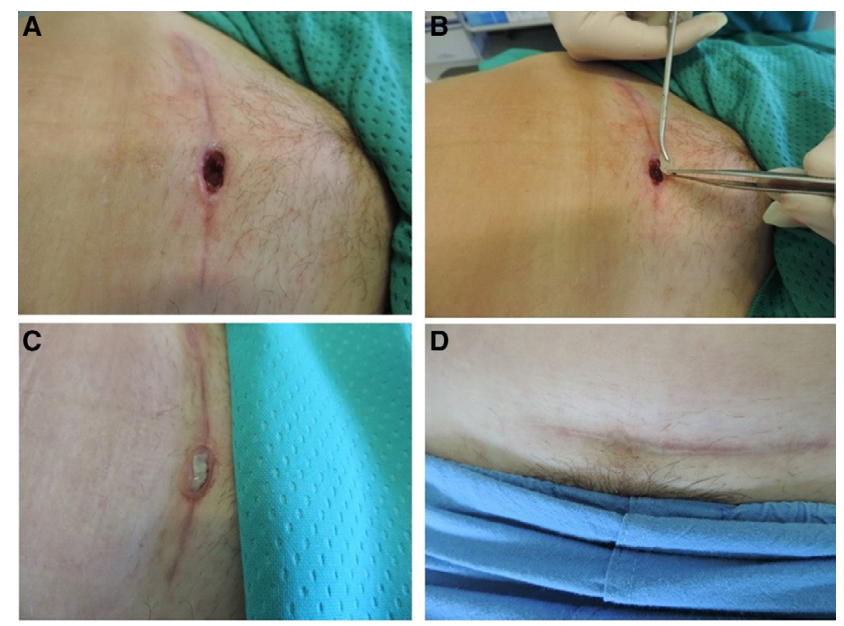

Figure I4 Application of lyophilized acellular gamma-irradiated dermis (DED LIO) over a dehisced surgical wound (gastric-onchologic surgery). (A,B,C) Complete healing assessed after 30 days; (D) with integration of DED LIO into the wound bed Abbreviation: DED-LIO, de-epidermized dermis liophilized.

available today for wound treatment, ${ }^{73,74}$ viable allogeneic human skin allografts remain a major therapeutic choice for extensive deep burns and hard-to-heal wounds. For patients with such lesions, viable skin allografts have significantly improved clinical outcomes with respect to unviable humanderived allografts and synthetic medications.

Further clinical indications for skin bank bioproducts include orthopedic trauma with bone-tendon exposure, dental surgery, maxillo-facial reconstruction, reconstruction of critical areas of the face, nasal septum or tympanic reconstruction, chronic full-thickness ulcers, posttraumatic and surgical wounds and pressure ulcers, autoimmune and infectious skin

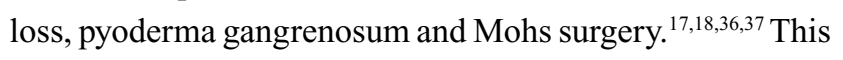
explains the increased demand for homologous skin/dermis from tissue banks.

This demand for human-derived skin bioproducts continues to support the existence of skin banks. However, it is worth bearing in mind that despite serological and microbiological screening of donors to exclude transmissible diseases, as well as careful donor selection and rigorous quality control in tissue preparation, bioproducts carry a certain risk of transmission of pathogenic agents. It is therefore necessary to assess risks/ benefits, obtain full informed consent and take into account contraindications such as infected, non-debrided skin lesions, skin cancers and intolerance/allergy to antibiotics used in skin processing. Tissue banks differ in their techniques for preservation and storage of human skin allografts. They need to guarantee standardized methods, reproducible procedures, traceability and safety in all phases of processing in order to avoid new biological contamination. Consistent, reproducible operating standards with periodic checks, and continuous 
training and improvement of quality objectives help maintain a high level of attention and responsibility among operators and lead to progressive quality improvement. ${ }^{17,27,32,37}$

The central role of tissue establishments in providing tissue grafts for clinical use highlights the complex network linking donors and recipients. Tissue banks often encounter difficulty in supplying material to final clinical users. Besides, demand for tissue allografts depends on the one hand on scientific developments that make new treatments possible and support tissue bank activity, but on the other hand on new alternatives that may lead to reduced demand for bioproducts.

Most tissue banks have recently been involved in providing skin and other tissue grafts in critical incidents and disasters, demonstrating their central role as a source of materials for immediate needs in emergencies and catastrophic events.

\section{Disclosure}

The authors report no conflicts of interest in this work.

\section{References}

1. Webster JP. Refrigerated skin grafts. Ann Surg. 1944;120(4):431-439.

2. Matthews DN. Storage of skin for autogenous grafts. Lancet. $1945 ; 2: 775-758$.

3. Barker CF, Markmann JF. Historical overview of transplantation. Cold Spring Harb Perspect Med. 2013;3(4):a014977.

4. McCauley RL. The skin bank. Total burn care. 1st ed. Philadelphia, PA: Saunders; 1996:159-163.

5. Mericka P. Brief history of the tissue bank, Charles University Hospital, Hradec Kralove, Czech Republic. Cell Tissue Bank. 2000;1(1):17-25.

6. Freedlander E, Boyce S, Ghosh M, Ralston DR, MacNeil S. Skin banking in the UK: the need for proper organization. Burns. 1998;24(1):19-24.

7. Pianigiani E, Ierardi F, Cherubini Di Simplicio F, Andreassi A. Skin bank organization. Clin Dermatol. 2005;23(4):353-356.

8. Matesanz R, Mirand B, Felipe C, Fernandez M, Naya MT. The national transplant organization - donation evolution and transplant activity in Spain. Ann Transplant. 1996;1(3):45-56.

9. Allorto NL, Rogers AD, Rode H. "Getting under our skin": introducing allograft skin to burn surgery in South Africa. S Afr Med J. 2016;106(9):865-866.

10. Gore MA, De AS. Deceased donor skin allograft banking: response and utilization. Indian J Plast Surg. 2010;43(Suppl):S114-S120.

11. Martínez-Floresa F, Chacón-Gómeza M, Madinaveitia-Villanueva JA, Barrera-Lopez A, Aguirre-Cruz L, Querevalu-Murillo W. [The clinical use of cryopreserved human skin allografts for transplantation.] Cir Cir. 2015;83(6):485-491. Spanish.

12. Saffle JR. Closure of the excised burn wound: temporary skin substitutes. Clin Plast Surg. 2009;36(4):627-641.

13. Leon-Villapalos J, Eldardiri M, Dziewulski P. The use of human deceased donor skin allografts in burn care. Cell Tissue Bank. 2010;11(1): 99-104.

14. Gaucher S, Jarraya M. Cryopreserved human skin allografts: efficacy and viability. Burns. 2014;40(3):526-527.

15. Kagan RJ, Robb EC, Plessinger RT. Human skin banking. Clin Lab Med_2005;25(3):587-605.

16. Kearney JN. Guidelines on processing and clinical use of skin allografts. Clin Dermatol. 2005;23(4):357-364.

17. Gaucher S, Elie C, Verola O, Jarraya M. Viability of cryopreserved human skin allografts: effects of transport media and cryoprotectants. Cell Tissue Bank. 2012;13(1):147-155.
18. Official Journal of the European Union. Directive 2004/23/EC of the European Parliament and Council on quality and safety standards for the donation, procurement, testing, processing, preservation, storage and distribution of human tissues and cells. Official Journal of the European Union; 2004. Available from: http://eur-lex.europa.eu/ Lex-UriServ/LexUriServ.do?uri=OJ:L:2004:102:0048:0058:en:PDF. Accessed June 5, 2017.

19. Commission Directive 2006/17/EC implementing Directive 2004/23/ EC of the European Parliament and of the Council as regards certain technical requirements for the donation, procurement and testing of human tissues and cells. Available from: http://eur-lex.europa.eu/legalcontent/EN/TXT/?uri=celex\%3A32006L0017. Accessed June 5, 2017.

20. Commission Directive 2006/86/EC implementing Directive 2004/23/ EC of the European Parliament and of the Council as regards traceability requirements, notification of serious adverse reactions and events and certain technical requirements for the coding, processing, preservation, storage and distribution of human tissues and cells. Available from: http://eur-lex.europa.eu/legal-content/EN/ TXT/?uri=celex\%3A32006L0086. Accessed June 5, 2017.

21. European commission [homepage on the Internet]. EudraLex - Volume 4 - Good Manufacturing Practice (GMP) guidelines; 2010 [updated December, 2010]. Available at: https://ec.europa.eu/health/documents/ eudralex/vol-4_en. Accessed June 29, 2017.

22. Ireland L, McKelvie H. Tissue banking in Australia. Cell Tissue Bank. $2003 ; 4(2-4): 151-156$.

23. Linee guida per il prelievo, la processazione e la distribuzione dei tessuti a scopo di trapianto - Centro Nazionale per i Trapianti (CNT); 2015. Available from: http://www.trapianti.salute.gov.it. Accessed January 2, 2017.

24. European Directorate for the Quality of medicines \& Health Care (EDQM). Guide to the quality and safety of tissues and cells for human application. France; 2015. Available from https://www.edqm.eu/sites/ default/files/foreword_list_of_contents_tissues_cell_guide_2nd_edition_2015.pdf. Accessed June 5, 2017.

25. Vicentino M, Rodriguez G, Saldias M, Alvarez I. Guidelines to implement quality management systems in microbiology laboratories for tissue banking. Transplant Proc. 2009;41(8):3481-3484.

26. Kearney JN. Quality issues in skin banking: a review. Burns. 1998;24(4):299-305.

27. Code of Federal Regulations. Title 21, Chapter 1, Subchapter L, Volume 8 [Revised as of April 1, 2016]. Part 1271: Human cells, tissues and cellular and tissue-based products. Subpart D: Current Good Tissue Practice. Sec. 1271.215: Recovery

28. Pianigiani E, Ierardi F, Fimiani M. Importance of good manufacturing practices in microbiological monitoring in processing human tissues for transplant. Cell Tissue Bank. 2013;14(4):601-607.

29. Verbeken G, Verween G, De Vos D, et al. Glycerol treatment as recovery procedure for cryopreserved human skin allografts positive for bacteria and fungi. Cell Tissue Bank. 2012;13(1):1-7.

30. Pianigiani E, Ierardi F, Cuciti C, Brignali S, Oggioni M, Fimiani M. Processing efficacy in relation to microbial contamination of skin allografts from 723 donors. Burns. 2010;36(3):347-351.

31. Pianigiani E, Risulo M, Ierardi F, et al. Prevalence of skin allograft discards as a result of serological and molecular microbiological screening in a regional skin bank in Italy. Burns. 2006;32(3):348-351.

32. Pirnay JP, Verween G, Pascual B, et al. Evaluation of a microbiological screening and acceptance procedure for cryopreserved skin allografts based on 14-day cultures. Cell Tissue Bank. 2012;13(2):287-295.

33. Castagnoli C, Alotto D, Cambieri I, et al. Evaluation of donor skin viability: fresh and cryopreserved skin using tetrazolium salt assay. Burns. 2003;29(8):759-767.

34. Franchini M, Zanini D, Bosinelli A, et al. Evaluation of cryopreserved donor skin viability: the experience of the regional tissue bank of Verona. Blood Transfus. 2009;7(2):100-105.

35. Kua EH, Goh CQ, Ting Y, Chua A, Song C. Comparing the use of glycerol preserved and cryopreserved allogenic skin for the treatment of severe burns: differences in clinical outcomes and in vitro tissue viability. Cell Tissue Bank. 2012;13(2):269-279. 
36. Pianigiani E, Tognetti L, Ierardi F, et al. Assessment of cryopreserved donor skin viability: the experience of the regional tissue bank of Siena. Cell Tissue Bank. 2016;17(2):241-253.

37. Hermans MHE. Preservation methods of allografts and their (lack of) influence on clinical results in partial thickness burns. Burns. 2011;37(5):873-881.

38. Cleland H, Wasiak J, Dobson $H$, et al. Clinical application and viability of cryopreserved cadaveric skin allografts in severe burns: a retrospective analysis. Burns. 2014;40(1):61-66.

39. Van Baare J, Cameron PU, Vardaxis N, et al. Comparison of glycerol preservation with cryopreservation methods on HIV-1 inactivation. J Burn Care Rehabil. 1998;19(6):494-500.

40. Blondet R, Gibert-Thevenin MA, Pierre C, Ehrsam A. Skin preservation by programmed freezing. Br J Plast Surg. 1982;35:530-536.

41. Livesey SA, Herndon DN, Hollyoak MA, Atkinson YH, Nag A. Transplanted acellular allograft dermal matrix. Transplantation. 1995;60(1):1-9.

42. Johnston C, Callum J, Mohr J, et al. Disinfection of human skin allografts in tissue banking: a systematic review report. Cell Tissue Bank. 2016;17(4):585-592.

43. Ferrando PM, Balmativola B, Cambieri I, et al. Glycerolized reticular dermis as a new human acellular dermal matrix: an exploratory study. PloS One. 2016;11(2):e0149124.

44. May SR, Roberts DP. Development of a passive device for freezing large amounts of transplantable skin at one time in a $-70^{\circ} \mathrm{C}$ mechanical refrigerator. Cryobiology. 1988;25(3):186-196.

45. Bravo D, Rigley TH, Gibran N, Strong DM, Newman-Gage H. Effect of storage and preservation methods on viability in transplantable human skin allografts. Burns. 2000;26(4):367-378.

46. Schiozer WA, Gemperli R, Mu"hlbauer W, et al. An outcome analysis and long-term viability of cryopreserved cultured epidermal allografts. Assessment of the conservation of transplantable human skin allografts. Acta Cir Bras. 2013;28(12):824-832.

47. Li Z, Overend C, Maitz P, Kennedy P. Quality evaluation of meshed split-thickness skin grafts stored at $4^{\circ} \mathrm{C}$ in isotonic solutions and nutrient media by cell cultures. Burns. 2012;38(6):899-907.

48. Udoh Y, Yanaga H, Tai Y, et al. Long-term viability of cryopreserved cultured epithelial grafts. Burns. 2000:26(6):535-542.

49. Robb EC, Bechmann N, Plessinger RT, et al. Storage media and temperature maintain normal anatomy of cadaveric human skin for transplantation to full-thickness skin wounds. J Burn Care Rehabil. 2001;22(6):393-396

50. Walcerz DB, Karow AM. Cryopreservation of cells for tissue engineering. Tissue Eng. 1996; 2(2):85-96.

51. De Luca M, Albanese E, Bondanza S, et al. Multicentre experience in the treatment of burns with autologous and allogenic cultured epithelium, fresh or preserved in a frozen state. Burns. 1989;15(5):303-309.

52. Teepe RGC, Koebrugge EJ, Ponec M, Vermeer BJ. Fresh versus cryopreserved cultured allografts for the treatment of chronic skin ulcers British Journal of Dermatology, 1990;122:81-89.

53. Mackie DP. The Euro Skin Bank: development and application of glycerol-preserved allografts. J Burn Care Rehabil, 1997;18(1):S7-S9.

54. Mackie D. Postal survey on the use of glycerol-preserved allografts in clinical practice. Burns. 2002;28(Suppl. 1):S40-S44.

55. Blome-Eberwein S, Jester A, Kuentscher M, Raff T, Germann G, Pelzer M. Clinical practice of glycerol-preserved allograft skin coverage. Burns. 2002;28(Suppl. 1):S10-S12.
56. Wood JM, Soldin M, Shaw TJ, Szarko M. The biomechanical and histological sequelae of common skin banking methods. J Biomech. 2014;47(5):1215-1219.

57. Schirmbeck T. Biomechanical and histological evaluation of glycerolpreserved human sclerae. Arq Bras Oftalmol. 2007;70(6):988-990.

58. Saegeman VS, Ectors NL, Lismont D, Verduyckt B, Verhaegen J. Short- and long-term bacterial inhibiting effect of high concentrations of glycerol used in the preservation of skin allografts. Burns. 2008;34(2):205-211.

59. Hamilton KT, Herson MR. Skin bank development and critical incident response. Cell Tissue Bank. 2011;12(2):147-151.

60. Khoo TL, Halim AS, Mat Saad AZ, Dorai AA. The application of glycerol-preserved skin allograft in the treatment of burn injuries: An analysis based on indications. Burns. 2010;36(8):97-904

61. Vloemans AF, Schreinemachers MC, Middelkoop E, Kreis RW. The use of glycerol-preserved allografts in the Beverwijk Burn Centre: a retrospective study. Burns, 2002;28(Suppl. 1):S2-S9.

62. Singh R, Singh D, Singh A. Radiation sterilization of tissue allografts: A review. World J Radiol. 2016;8(4):355-369.

63. Rooney P, Eagle M, Hogg P, et al. Sterilisation of skin allograft with gamma irradiation. Burns. 2008;34(5):664-673.

64. Dearth CL, Keane TJ, Carruthers CA, et al. The effect of terminal sterilization on the material properties and in vivo remodeling of a porcine dermal biologic scaffold. Acta Biomater. 2016;33:78-87.

65. Gilbert TW, Sellaro TL, Badylak SF. Decellularization of tissues and organs. Biomaterials. 2006;27(19):3675-3683.

66. Pianigiani E, Tognetti L, Ierardi F, et al. Il derma acellulare liofilizzato. Hi-Tech Dermo. 2016;3:17-20.

67. Hauben, DJ, Baruchin A, Mahler A. On the history of the free skin graft. Ann Plast Surg. 1982;9(3):242-245.

68. Eurocode.org [database on the Internet]. Germany: Eurocode IBLS; 2013. Available from: http://www.eurocode.org/tables/products/index. html. Section:products code catalogue/tissue/751001/F:tissue preservation. Accessed June 5, 2017.

69. Blair R. Guide and bibliography for research into the skin homograft problem. Plast Reconstr Surg (1946). 1951;7(3):169-201.

70. Gibson T, Medawar PB. The fate of skin homografts in man. J Anat. 1943;77(Pt 4):299-310.

71. Cuono CB, Langdon R, Birchall N, et al. Composite autologousallogeneic skin replacement: development and clinical application. Plast Reconstr Surg. 1987;80(4):626-637.

72. Alexander JW, MacMillan BG, Law E, et al. Treatment of severe burns with widely meshed skin autograft and widely meshed skin allograft overlay. J Trauma. 1981;21(6):433-438

73. Debels H, Hamdi M, Abberton K, Morrison W. Dermal matrices and bioengineered skin substitutes: a critical review of current options. Plast Reconstr Surg Glob Open. 2015;3(1):e284.

74. Fimiani M, Pianigiani E, Di Simplicio FC, et al. Other uses of homologous skin grafts and skin bank bioproducts. Clin Dermatol. 2005;23(4): 396-402.

75. Human tissue intended for transplantation-FDA. Interim rule; opportunity for public comment. Fed Regist. 1993;58(238):65514-65552.

76. Dickinson LE, Gerecht S. Engineered biopolymeric scaffolds for chronic wound healing. Front Physiol. 2016;7:341.

77. Strong DM. The US Navy Tissue Bank: 50 years on the cutting edge Cell and Tissue Banking. 2000;1(1):9-16. 


\section{Publish your work in this journal}

The Journal of Biorepository Science for Applied Medicine is an international, peerreviewed, open access journal that focuses on new developments and advances in the emerging and evolving field of biorepository science. This includes biospecimen procurement, processing, preservation, and banking for application to applied medicine. The Journal invites submission of manuscripts which address these aspects in addition to systems logic, clinical throughput and ethical issues pertaining to application of

Submit your manuscript here: https://www.dovepress.com/journal-of-biorepository-science-for-applied-medicine-journal biorepositories and their effects on clinical medicine. The journal is characterized by the rapid reporting of reviews, original research, methodologies, technologies and analytics in this subject area. The manuscript management system is completely online and includes a very quick and fair peer-review system, which is all easy to use. Visit http:// www.dovepress.com/testimonials.php to read real quotes from published authors. 